\title{
The Construction of the Pioneer Figure in the North of Paraná: Debates and Perspectives
}

\author{
Sandra de Cássia Araújo Pelegrini, João Paulo Pacheco Rodrigues
}

Department of History, State University of Maringá, Maringá, Brazil

Email address:

sandrapelegrini@yahoo.com.br (S. de C.A. Pelegrini), Joaopacheco2210@hotmail.com (J. P. P. Rodrigues)

\section{To cite this article:}

Sandra de CáSsia AraúJo Pelegrini, João Paulo Pacheco Rodrigues. The Construction of the Pioneer Figure in the North of Paraná: Debates and Perspectives. History Research. Vol. 6, No. 1, 2018, pp. 15-21. doi: 10.11648/j.history.20180601.12

Received: May 18, 2018; Accepted: June 14, 2018; Published: July 10, 2018

\begin{abstract}
Ivatuba is a city in the state of Paraná, located in the southern region of Brazil. Its reoccupation process took place around the 1940s through Companhia de Terras Norte do Paraná and later Companhia de Melhoramentos Norte do Paraná, companies derived from the former Parana Plantations, a British capital company that was granted the right to installment and sale of land over an extensive region that goes from Jataizinho to Umuarama. Ivatuba became a municipality in 1961, later, as a way to commemorate its 25 -year history was published the magazine "Ivatuba Progress Constant." In this article, an analysis of this publication is presented, seeking to understand the construction of some discourses about the collective memory of Ivatuba, from the point of view of the "pioneer", considered a fundamental and percussive agent of the occupation and expansion of the city.
\end{abstract}

Keywords: Regional History, Memory, Images, Pioneering, Newspapers, Cultural History

\section{Introduction}

Understanding the peculiarities and sociocultural characteristics of a particular region has become an arduous task for the historian. Cities, neighborhoods and villages are, above all, dynamic places, where present a plurality of historical subjects and actors. Beyond the minute look geographic, agrarian, symbolic and religious boundaries, the researcher regional studies should focus on sociability networks. Built over time and merged into these spaces.

Ivatuba is located in the northern region of Paraná (Brazil) and $468 \mathrm{~km}$ from the capital Curitiba. The municipality was part of the process of reoccupation that advanced at a rapid pace in the mid-twentieth century. Northern Paraná, as already pointed out consistent research on the subject, had already been a place of human occupation for a long time. As Mota points out, the place was already occupied by indigenous populations some 8,000 years ago, and may even reach 13,000 years.

The region also underwent military reconnaissance expeditions and Jesuit reductions over time, reaching the 20th century with some areas occupied by farmers. However, since the 1930s, it has undergone a process of splitting, commercializing and occupying the land in a more offensive way, the so-called capitalist occupation. As of this decade, with the operation of colonization companies, among them the Companhia de Terras Norte do Paraná (C.T.N.P.), which was to become Companhia Melhoramentos Norte do Paraná (C.M.N.P.) in the middle of 1940, companies derived from the former Parana Plantations, a British capital company that was granted the right to installment and sale of land over an extensive region that goes from Jataizinho to Umuarama..

Through the work of this real estate company, a large part of its area was re-occupied, with the planting of extensive coffee plantations, replacing the forest and the implantation of railroads, highways and the foundation of cities. As shown in the following map, this advance begins in the city of Londrina, from 1930 and persists until the mid-1950s. 


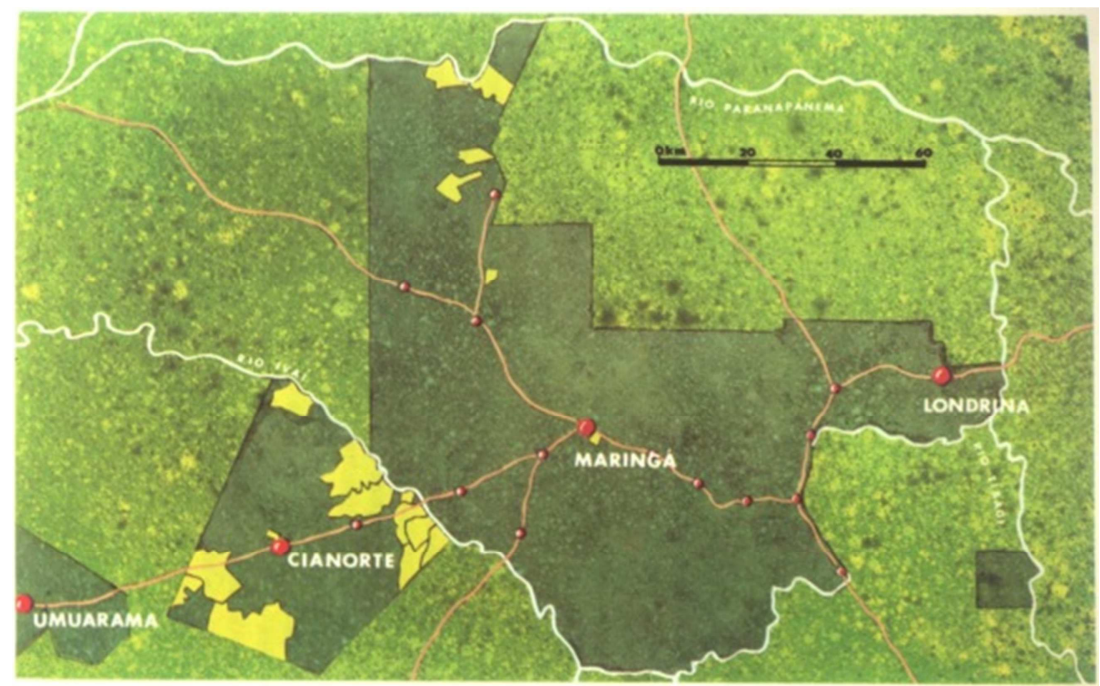

Figure 1. Occupation of the northern region of Paraná, highlighting the area marketed by C.T.N.P./C.M.N.P. Source: CMNP, 1975.

\section{Agricultural Frontiers in the Reoccupation Process}

The methodological contributions of this research focused on the fields of Microhistory. It is worth remembering that the Micro-History referred to the historiographic proposition elaborated by a group of Italian historians in the late 1970s, such as Carlo Ginzburg and Giovanni Levi, who demonstrated some discontent with the structural and quantitative history. In this sense, they proposed a change of scale for historical analysis. However, changing the scale of observation does not mean representing a constant reality in a larger or smaller size, but rather transforming the content of the representation.

The historians who dedicated themselves to Microhistory were convinced that the lives of diverse people were also part of history, and through it it would be possible to reconstruct certain contexts from the experiences of individuals
Based in this methodological support, in which he tries to analyze the hidden subjects of history, that is, that soldier of a great war, a certain policeman during the military dictatorship in Brazil in 1964, or the story of a woman during a labor strike in the Revolution Industrial. We seek to understand the construction of the figure of the pioneer in the north of the state of Paraná

In the region of Ivatuba. Ivatuba, as well as hundreds of small towns in the northern region of Paraná, are fruits of this occupation process. The actual settlement of the city of Ivatuba occurred after the acquisition of the land near Rio Ivaí by Pareja e Cia Ltda, marketed by Companhia Melhoramentos Norte do Paraná.

The city is bathed by the Rio Ivaí. With an area of 36,587 $\mathrm{km}^{2}$ and a route of $680 \mathrm{~km}$, the river is a tributary of the left bank of the Upper Paraná River and has an average flow of 363 cubic meters. From its waters are born other streams like Ribeirao Taquaruçu, Ribeirão Paiçandu and Água Ivatuba, as we can see in the following image.

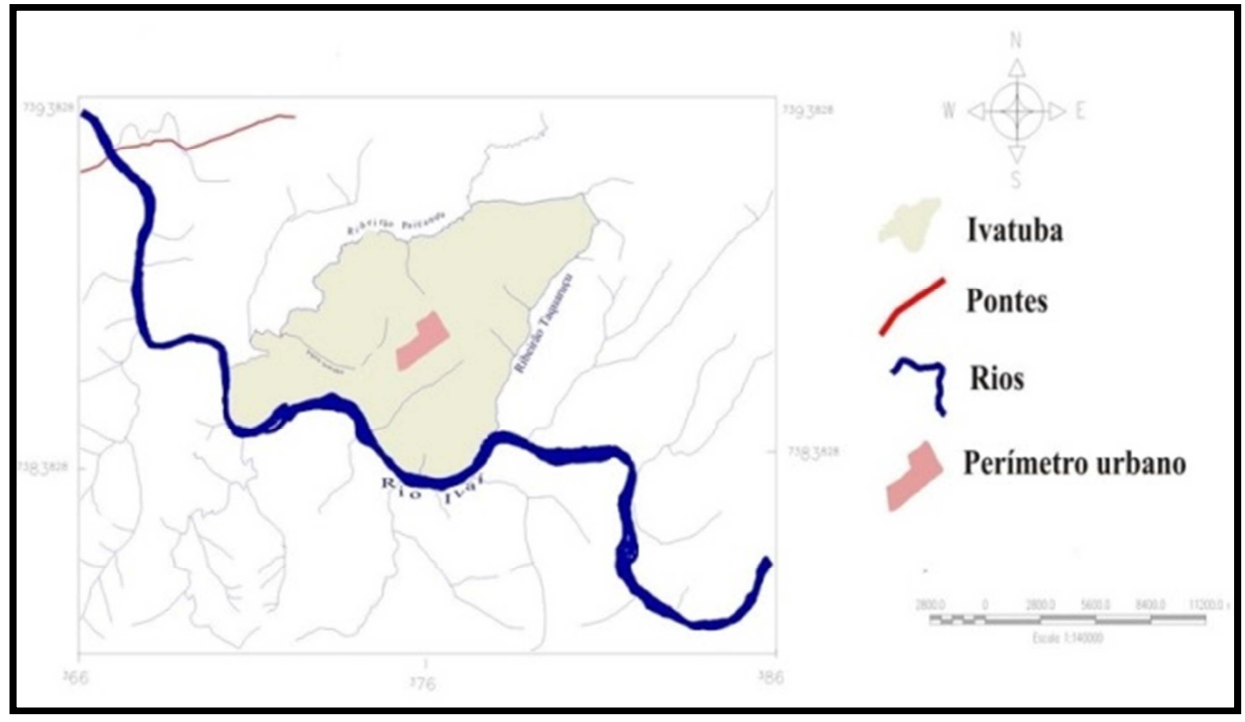

Figure 2. Municipality of Ivatuba. Author: João Paulo Pacheco Rodrigues. 
In 1949, Primo Francisco Mazzuco from Santa Catarina and the Italian from Gravatal-SC Estevão Grasso acquired a strip of land from the said company and founded Grasso and Mazzuco Ltda. In the magazine "Ivatuba Progresso Constante" by Antônio Padilha, Mazzuco, born in Urussanga, Santa Catarina, is treated as an adventurer and a futurist visionary.

The author mentions the Santa Catarina as one of the main "pioneers" who faced the "wild hinterland" and the "virgin forest". In the same publication, Grasso is mentioned as the main founder of Ivatuba, the journal mentions the great achievements of the Italian in the region and highlights the donations of land for the Catholic Church and the main public agencies. In the same year, the two "entrepreneurs" began to resell the first rural properties for the families coming from the North of the State of Santa Catarina. Like C.T.N.P / C.M.N.P.,

This smaller company used advertising as a decoy, supported in two aspects: the first on soil fertility, the purple earth, according to the company would be extremely productive for the cultivation of the most varied products; the second aspect may be related to the presence of Rio Ivaí in the region, since many migrants were dazzled by the possibility of acquiring these lands near the river, because this would help the implantation of the coffee plantations, yielding water and mainly, legitimating the fertility of the river. ground.

The first records of the founders of the city date back to August 19, 1949, when Santa Catarina, born in Nova Veneza, Santo Presa and Leonildo Coral, bought a site of 7 alqueires destined for coffee cultivation. In the same year, Francisco Zampronio, native of Ararangua-SC, acquired a small property near the Água Paiçandu site. In 1950, the first families from the state of São Paulo migrated, among whom Padilha (1981) mentions Antonio Acetti, a native of Ituverava, José Dante born in Guairá-SP, Silvestre Dante, from São José do Rio Pardo- SP. and Eduardo Rodrigues Garcia, from Ibarra-SP.

In 1950, the first families from the state of São Paulo migrated, among whom Padilha (1981) mentions Antonio Acetti, a native of Ituverava, José Dante born in Guairá-SP, Silvestre Dante, from São José do Rio Pardo- SP. and Eduardo Rodrigues Garcia, from Ibarra-SP.

On July 11, 1951, the town was elevated to Maringá district. On July 25, 1960, elevated to the municipality, and on November 18, 1961, the solemn installation was held officially with the inauguration of the first elected mayor, Vander Ribeiro, a native of Campina Grande do Sul, Paraná.

During the 1960s, hundreds of natural families from these two states and interested in growing coffee crops, migrated to the region. This movement was also present during the occupation of northern Paraná, thus comprising a pioneering expansion front.

Before the action of the Improvement Company of the North of Paraná at the beginning of the twentieth century, the region already had a relative migratory flow, mainly from coffee producers in the state of São Paulo. However, after the performance of the Company of Improvements of the North of Paraná we observe a progress of the pioneer front of expansion in the occupation of the region where today is located Ivatuba ${ }^{1}$. As a consequence of this process a relative increase in the number of coffee farms of the traditional São Paulo type, in addition to the population growth in the territory of Paraná.

In 1960, the demographic density of the state was of 21,5 hab. $/ \mathrm{km}^{2}$, in the regions of the north and the west, where the occupation was still solidifying the number was already 33.4 hab. $/ \mathrm{km}^{2}$. According to Luz (1997), by the demographic census of the same year, there were 162 cities in the state, of which 48 with a population mass greater than 5 thousand inhabitants, and 27 of these in the northern region of Paraná

If in the 1950s and 1960s the migratory flow predominated in the north of the state, mainly in the region of São Paulo, in Ivatuba, we can see some disparities regarding this process.

When analyzing the periodical "Ivatuba Progresso Constante", we observed that the great majority of the families mentioned in the magazine originated in the state of São Paulo and especially in Santa Catarina. This nuance probably is due to the fact that the founders of the company Mazzuco and Grasso Ltda, are of Santa Catarina origin, which favored the sale of lots of the region for its countrymen. Another aspect that should be taken into account is that most of the families that migrated to the region brought with them several other groups of the same kinship.

As an example of this, we can highlight the Santo Presa lords in 1949, Olívio and Paulo Presa in the same year and Olinto Presa in 1952, all natural of New Venice. Also the farmers Fridolino Michelis, in 1952 and Hugo Evaristo Michelis, in 1955, originating from Criciúma, Santa Catarina.

It should be noted that, although most of the families that migrated to the region had the objective of acquiring sites and lots for coffee production, this was not the only economic activity developed in the territory. Aurelio Semperom as one of the first local merchants in the early $1950 \mathrm{~s}$, as well as Mr. José Bendo in the construction of the region's first Ceramics in 1951, a period in which Ivatuba still established itself as a village. Thus we observe that the agrarian borders were determinant for the re-occupation of the Ivatuba region. Because coffee cultivation in this period was the main factor for the migration of these populations.

According to Nadir Cancian after World War II coffee production has undergone some changes, with coffee prices increasing and the production center from São Paulo to Paraná, mainly in the north of the state 1951, Norte Novissimo in 1962 and in 1965 again the New North), where it was configured as the biggest dynamic center of the activity. It should be noted that the Ivatuba region is located in the New North of the state, as we observe in the map below.

[1] LUZ, France. O Fenômeno Urbano numa zona pioneira: Maringá. Dissertação (Mestrado em História Social) - Faculdade de Filosofia, Letras e Ciências Humanas da Universidade de São Paulo, São Paulo, 1980. 


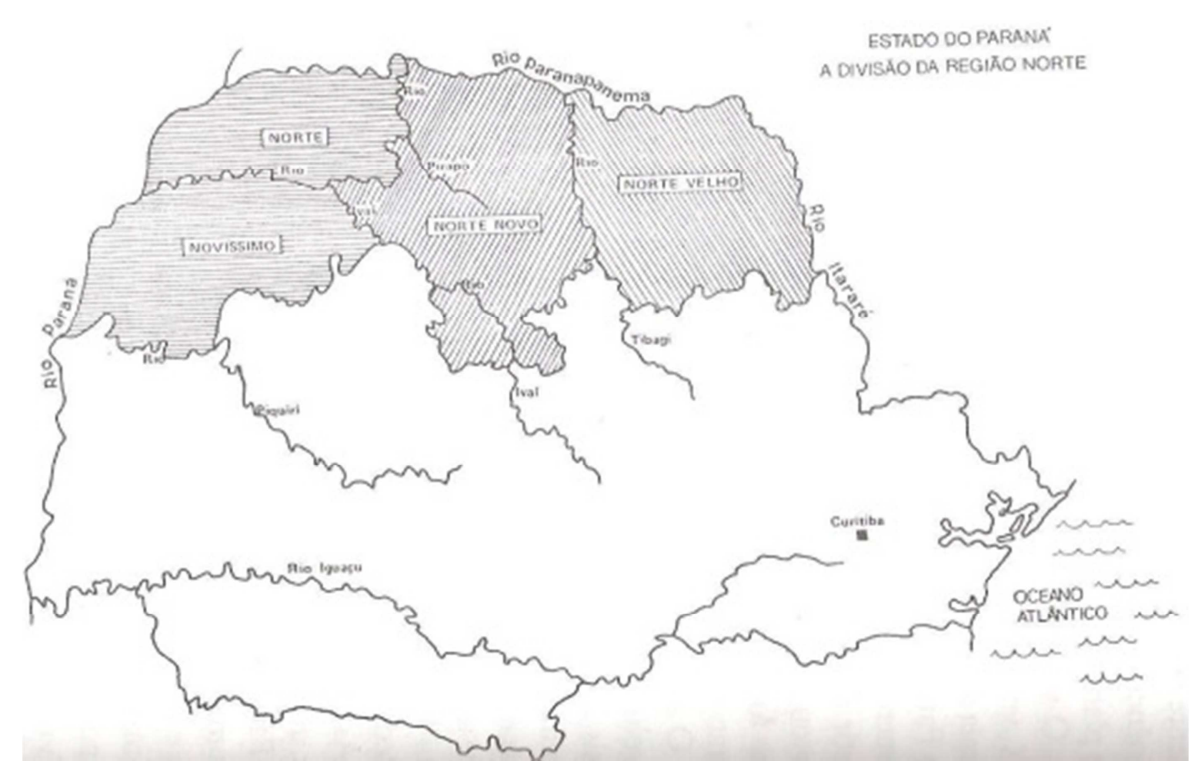

Figure 3. State of Paraná, the division of the North region. In Luz (1997, p. 26).

Second Martins (1997). From the moment the first frosts occurred, liquidating innumerable coffee plantations, the pioneer expansion in the city of Ivatuba, had gradually lost its strength. In the late 1970s, the rural population of Ivatuba declined dramatically, and many farmers abandoned coffee cultivation and began to dedicate themselves to other crops such as soybeans, corn and wheat, which are still present in the region.

Thus, it is possible to consider the presence of two pioneering fronts of expansion in Ivatuba, the first one originating in the state of São Paulo and common in the process of occupation of the north of the state and the second originating in Santa Catarina, region in which the founders of the company responsible for the sales of lots came from.

\section{The city of Ivatuba and Its Memories: Study of Ivatub Progressive Magazine}

As was pointed out previously in this text, to specifically discuss the case of Ivatuba was elected in this paper a journal for analysis. In 1985, at the request of then-Mayor Adolfo Semperbom, the journalist Antonio Padilha wrote and organized a magazine on the official history of the municipality of Ivatuba. The journal "Ivatuba Progresso Constante" was published the same year. In its pages one can see the narrative of the origin of the first migrants and the most "traditional" families of the city. Such an aspect reveals that probably, so much work, made to order, was financed and promoted by these same families, contemplated in its pages.

The magazine shows a colorful cover, on which rests the city's coat of arms along with three words, alongside: history, pioneers and news. Such designations will also mark the content content and focus of the publication. As can be seen in the image below, there is also the slogan of the municipal administration, highlighted (Work and Union -
Administration Adolfo Semperbom); in its left corner, the symbol of the fuel distributor Shell and, on the other side, a drawing of a handshake, alluding to the union's words of the then administration.

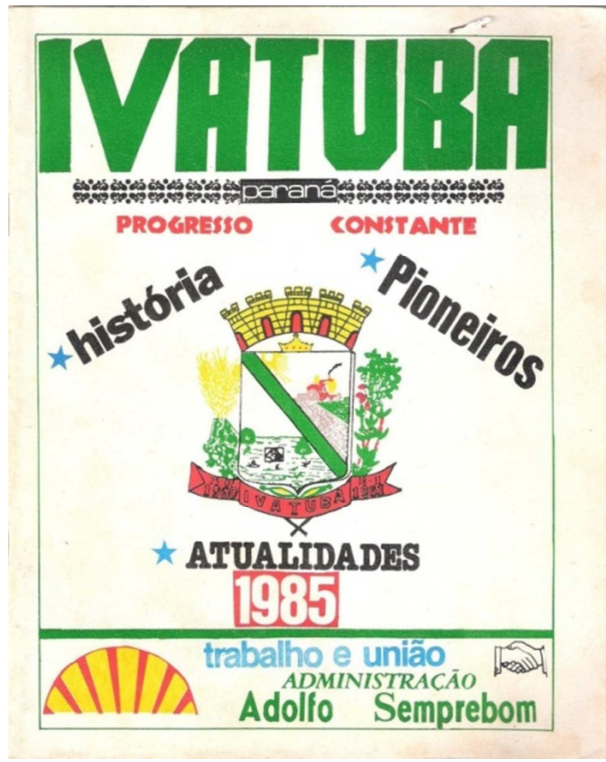

Figure 4. Cover of the magazine Ivatuba Progresso Constante." João E. G. Rodrigues Collection.

This publication has a total of 47 pages, divided as described below. Long on the second page, the General Data of the Municipality. In this item, it is reporting the number of inhabitants $(2,838$, in 1985), 3,023 voters, territorial expansion equivalent to $93,599 \mathrm{~km}^{2}$; Also found on this page are other data such as information on climate (hot and dry climate predominates), soil type (latos dystrophic purple soil (specific for agriculture), date of foundation (1949), district formation and emancipation.

The magazine also brings back information about the 
solemn installation on November 18, 1961, the number of commercial establishments (17), the amount of doctors and dentists, hospitals, gas stations, pharmacy, ceramics, social club. In this true "radiography" directed of the municipality of Ivatuba, it is noticed that all these mentioned will be subject of certain matter in the course of the magazine.

In the third and fourth pages, we have the topic A little of its History. In this part, it is narrated the history of the region of Ivatuba, after the action of the real estate company, in different moments. First, the Company Improvements of the North of Paraná that commercializes this parcel of land with the company Pareja e Cia. This same strip of lands later was partly resold for the Primo Francisco Mazzuco and Estevão Grasso, forming the company Grasso and Mazzuco ltda, which started to resell and resell the land for families from Santa Catarina and São Paulo.

The magazine mentions the first inhabitants and explorers of the region, the first commercial point and those responsible for "opening the forest" in the area that today is located the municipality of Ivatuba. Landfills in the urban area were carried out by Severino da Silvia (Velho Honório), Valdemar Alves Dias, Benedito Lima and others. The good quality lands attracted more and more families from the most diverse corners of the country. The first inhabitants of the urban area were Saudoso Santo Presa and Leonildo Coral, arrived on 19/8/49, coming from Santa Catarina and built their first ranches. The first merchant of the small village that began was the late Aurelio Semperbom who installed a small warehouse of dry and wet goods and general. (PADILHA, 1985, p26)

Alongside the citations, images illustrate the pioneer discourse and the process of occupation of these migrants. The first inhabitants of this region occupy the area as "pioneers", portrayed always surrounded by the forest and loaded with tools to tame it, like a hoe, a shovel, a machete. In a previous analysis, we noticed the existence of two components present in the images: The instruments of work and the fig tree.

The ax, hoe, machete can be considered symbols of work, in the condition that refer to the exploration of the "virgin forest" and wild nature. The fig tree may be related to soil fertility.

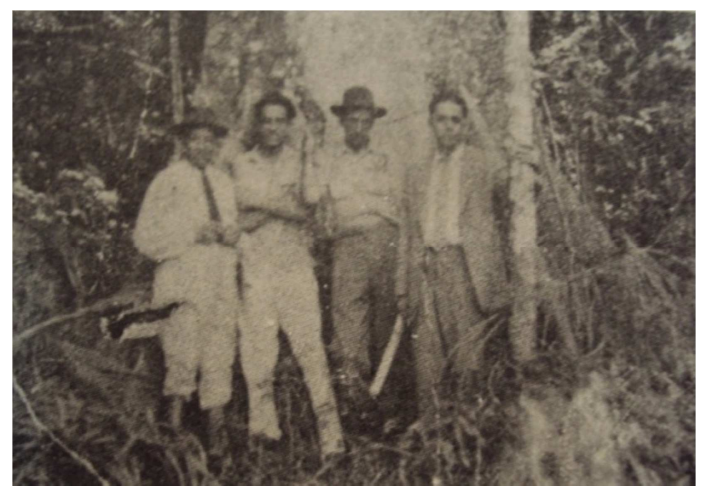

Figure 5. Photograph taken from the magazine Ivatuba Progresso Constante," the first migrants in the region.

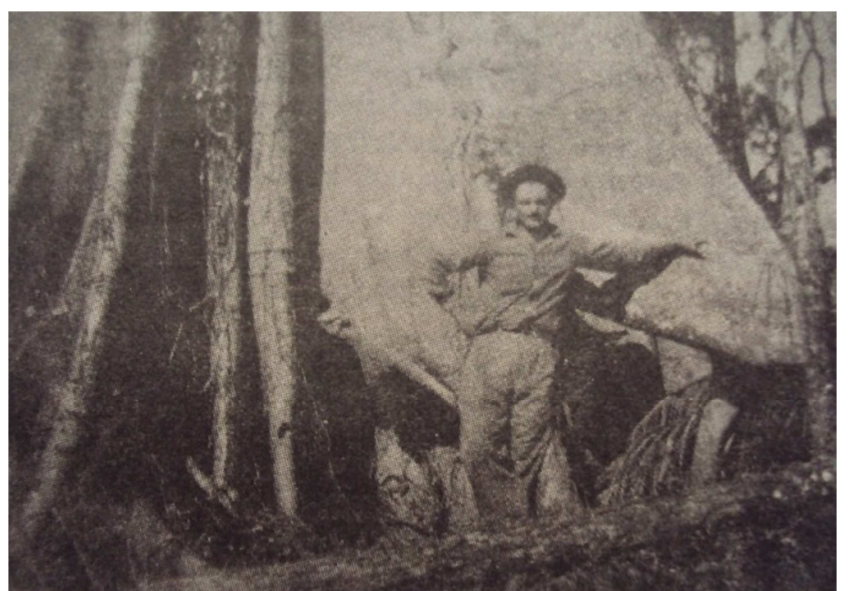

Figure 6. Photograph withdrawn from the Magazine "Ivatuba Progresso Constante", Otavio Perin.

To use the photographic image as a historical source it is necessary to realize, as states, that photography should not be analyzed only from its frozen image, since it is not a reflection of the real. In analyzing an image, it is crucial to consider that there is an inevitable bond between the photographer, the camera, and the subject matter that ultimately results from differentiated representations of the object and translates the view of the world from who captures the images. The use of image as a source of research can greatly enrich the knowledge and understanding of the past, however, it requires extreme care, the historian when analyzing a photograph must research the photographer's motivations, social relations and cultural, for what purpose and for whom the photo was produced. On the care that the historian must take when using imagery as a source of historical research.

We are attentive to the discussion about the magazine "Ivatuba Progresso Constante". Filling in pages 5 and 30, the theme is the traditional Pioneers and families, as the subtitle itself says. It is important to note that, in this title, the word "pioneer" is in bold letters, praising the importance of these to the process of occupation of the region.

In this section are portrayed all those considered the first residents of the municipality with their respective families. The registration always happens through a photograph of the couple or the family and, below, a small text narrating the personal trajectory of these individuals

In addition to a short biography of each migrant's life, his or her family tree, starting from those born in the municipality. This discourse can be understood as an attempt to legitimize the idea of the city, as hospitable and prosperous, in which the families there constituted their lives, as can be seen in the following quotation:

"Olinto Presa: It arrived in 1952, his late father arrived in 1949. He is married to Maria Coral Presa, having eleven children: Leomar, Juarez, Lorival, Cesar, Sergio, Maria Goretti, Marilene, Santo, Mariestael, Rosemeri, Valdirene, seven married, having 17 grandchildren. You are 62 years old. (P13)"

In the publication the first inhabitants of the region are 
presented as pioneers and explorers, fundamental subjects for the population and expansion of the city. According to Tomazi (1999), this denomination had its origin from the beginning of the process of re-occupation, in which these characters denominated as "pioneers" would be a way of enhancing the figure of certain individuals and depositing in the action of some people the force of the "regional strength".

Mentions Mr. Alvaro L. Godoy as one of those responsible for the formulation of this denomination that was disseminated during the $1970 \mathrm{~s}$ and $1980 \mathrm{~s}$ in historical studies. Tomazi (1999) considers the existence of this character as phantasmagorically idealized, to the point that all those employees of the company are silenced, who have overthrown and built a certain region. In the Ivatuba case, only the founders of the company Grasso and Mazzuco ltda, are prominent in the newspaper, thus hiding the fundamental agents in the occupation process.

From pages 31 to page 34 are shown the achievements of the Executive and Legislative Branch, citing the main works carried out and the future agreements signed with the state and federal government. There is also a quick biography of Mayor Adolfo Semperbom, highlighting the effort he has been making to achieve the improvements already achieved, such as the number of lighting poles, the increase of the car fleet, ambulances, improvements on the road connecting Ivatuba to the municipalities of Maringá and Floresta and a special highlight when citing the "political and administrative coordination" with the municipal leaders of the region.

Some images close with a "golden key", paraphrasing the local politicians, the textual discourses that indicated the proactive actions of the city hall in the search for other benefits for the citizens of Iiva, such as the cleaning of the streets, the central square and paving of some parts of the municipality. Such thematic cut-outs and the shrewdness in the distribution of images that accompany the stories demonstrate and leave no doubt as to the main sponsor of the journal

The magazine had a circulation of one thousand copies, of these about six hundred were donated to all the families of the city, in a specially organized ceremony so that the mayor handed them in the hands of its patriarchs. Center and fifty copies were destined to the Municipal Library and the remainder was destined to the divulgation promoted directly by the municipality. This procedure, recorded in photographs of the time and also in the speech of the municipal government treasurer in the eighties of the twentieth century, Mr. João EG Rodrigues, attest that in addition to the municipal politicians, the magazine received resources donated by families that would have been "properly" honored at the time.

\section{Conclusion}

We can verify that Ivatuba is configured as a small urban nucleus arranged in a rural area with approximately 96,786 $\mathrm{km} 2$. Until the second half of the twentieth century, this municipality had as its main product an agricultural practice that absorbed mainly the family labor, interspersed with other crops to support their families.

During the process of reoccupation of the city, in the second half of the twentieth century, we can observe the presence of the pioneer expansion frontage, based on coffee production. With an intense migratory flow of the states of São Paulo and Santa Catarina. This occupation happened essentially through the advance of the paulistas producers and of Santa Catarina; the former sought new and cheap land without any planting restrictions; the latter, reunited between the founders of the company Grasso and Mazzuco Ltda. involved in the process of marketing the lots especially among their fellow countrymen.

This occupation rooted in these two regions happened essentially through the advance of the paulistas producers who looked for new and cheap lands and without restrictions on the planting and also because the founders of the company Grasso and Mazzuco ltda, are natural of the state of Santa Catarina, helping the commercialization of the lots for their countrymen.

In this article, we also sought to reflect on the discourses and memoirs related to the pioneerism expressed and printed in the publication "Ivatuba Progresso Constante", in which we find that the written word and the images appear, side by side, complementing each other and attributing meanings to the experiences of individuals in different temporalities.

We were struck by two aspects: on the one hand, the fact that this journal omitted any reference to the indigenous presence in that region, where artifacts of its material culture were recently found amidst the plantations. And, on the other hand, the apparent willingness to overlook the rapid devastation of plant cover and its implications for the environment today. More importantly, this paper reinforced the idea that the occupation of northern "Paranaense" was orderly, harmonious, and without conflict, among the resident population and its younger descendants.

The construction of the memory of the so-called "pioneer front" remains, still today, ingrained and constitutes one of the arguments of "pride" and sense of belonging spread by politicians and other citizens in publications of a nature similar to "Ivatuba Constant Progress" revered in the civic ephemeris and other commemorative dates.

It is worth noting that the clashes between history and memory constitute a stalemate that accompanies researchers in the field of human sciences since a long time. Pelegrini and Delmonico, based on the theoretical assumptions of Jacques Le Goff (2003), assert that memory establishes a "link between the human generations and the historical time that accompanies them", making a parallel between "individual and collective memory" (Pelegrini Delmonico, 2009, p.335).

Le Goff considers that memory is "mythical, deformed and anachronistic." Mythical because it can be invented of something that did not exist; deformed because it can often omit or increase some aspect; and anachronistic for not using time, as a chronology - the memories simply come to the surface. The preserved memories are related to the traditions and cultural values that unite the groups that have identities and interests in common. Therefore, it is crucial to take the 
memories as a source to be explored through the story, through records of testimony or the collection of interviews.

Thus, it was verified that the arguments chosen to compose the memory of the municipality are in harmony with the "mythical image" reserved for the first local residents, that is, the pioneer, the pioneer and the winner, hiding the existence of other memories and stories resulting from the struggle for land and a "place in the sun."

\section{References}

[1] MOTA, Lucio Tadeu. História do Paraná: ocupação humana e relações interculturais. 1. ed. Maringá: EDUEM, 2005.

[2] TOMAZI, Nelson Dacio. "Norte do Paraná" História e Fantasmagorias. Tese (Doutorado em História) - Universidade Federal do Paraná, Curitiba, 1997.

[3] PELEGRINI, Sandra C. A e RODRIGUES, João P. P. Ivatuba: História, memória e tradição paranaense. Unicorpore. Maringá.2014.

[4] LUZ, France. O Fenômeno Urbano numa zona pioneira: Maringá. Dissertação (Mestrado em História Social) Faculdade de Filosofia, Letras e Ciências Humanas da Universidade de São Paulo, São Paulo, 1980.
[5] PADILHA, Antônio. "Ivatuba Progresso Constante" Londrina. Traço Publicações. 1985.

[6] CANCIAN, Nadir. Cafeicultura Paranense: 1900-1970. Tese (Doutorado em História) - Faculdade de Filosofia, Letras e Ciências Humanas da Universidade de São Paulo, São Paulo 1977.

[7] MARTINS, José de Souza. 1997. Fronteira. A degradação do Outro nos confins do humano. Editora Hucitec, São Paulo, Brasil.

[8] BURKE, Peter. Testemunha ocular. Bauru: EDUSC, 2004.

[9] TOMAZI, Nelson Dacio. "Norte do Paraná" História e Fantasmagorias. Tese (Doutorado em História) - Universidade Federal do Paraná, Curitiba, 1997.

[10] PELEGRINI, Sandra C. A.; DELMONICO, Renato. Patrimônio e apropriação popular na arquitetura modernista residencial de Maringá. In: CONGRESSO INTERNACIONAL DE HISTÓRIA, 4, 2009, Maringá. Anais... Maringá: UEM/PPH/DHI, 2009. v. 1. p. 4.314-4.323. $1 \mathrm{CD}$.

[11] LE GOFF, Jacques. Documento/monumento. In: História e memória. Trad. Irene Ferreira, Bernardo Leitão e Suzana Ferreira Borges. 5. ed. Campinas: Ed. da Unicamp, 2003. p. 525-539. 